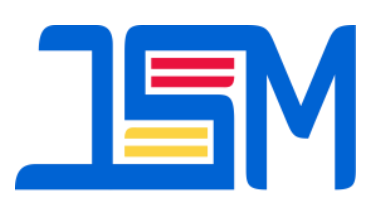

JAMBURA SCIENCE OF MANAGEMENT

\title{
The Influence Of The Work Environment On Employee Work Motivation At PT. Loka Indah Lestari Pohuwato
}

\author{
Ahmad Nawawi ${ }^{1}$, Abd. Rahman Pakaya ${ }^{2}$,Endi Rahman ${ }^{3}$ \\ ${ }^{1}$ Department of Management, Economic Faculty, Gorontalo State University \\ ${ }^{2,3}$ Economic Faculty, Gorontalo State University \\ E-mail: nawawi.manajemen015@gmail.com
}

\begin{abstract}
:
The research aimed to find out to what extent the effect of work environment on work motivation. The population of this research was all 74 permanent employees at PT. Loka Indah Lestari in Popayato Barat, Pohuwato. The analysis method used simple linear regression analysis. The result of analysis revealed that the work environment had a significant effect on work motivation from $t_{\text {count }} 3,975>t_{\text {table }} 1,666$ with a significance level of $0,000<0,05$. Thus, it found that work environment affected work motivation for $39,2 \%$ or it was low effect between work envornment on work motivation, and it certainly contained a phenomenon of lack of company attention to employees related to the work environment, particuraly inadequate road access and communication media (signal). Meanwhile, simultaneously work environment had a significant effect on work motivation through the test of R-value coefficient model, namely 0,424 , which meant a strong relationship. In addition, the value of $\mathrm{R}$ square was 0,180 or $18 \%$ whereas the rest 0,820 or $82 \%$ was affected by relationship with other factors out of this research.
\end{abstract}

\section{Keywords: Work Environment, Work Motivation}

The company has a big challenge in maintaining important assets, namely existing employees, especially in terms of employee motivation to be able to complete their performance targets. The company management positions motivation as a very important aspect, because its contribution is very significant in the context of achieving organizational goals, through managing human resources that are owned appropriately and relevantly, so new activities become motivation in working professionally. Scientists define motivation very diversely, according to Widodo (2015) "Motivation is the power that exists in a person, which encourages his behavior to take action."

Field information obtained by researchers from interviews with HRD staff on 5 February 2019 of PT. Loka Indah Lestari, namely there are still problems regarding the lack of employee motivation, especially work processes and 
conditions of work performed and it can be seen from employees who are sometimes not timely in completing work, then there are still some employees at work often procrastinating his job and tend to wait for encouragement from colleagues and superiors.

The existence of a significant relationship between work environment with work motivation shows that one of the factors that influence work motivation is the work environment (Arifin, 2015; Le Tran \& Chiou-su, 2015; Zameer et al, 2014). This is in line with the opinion of Sutrisno (2009) suggesting that external factors that influence employee motivation are: working environment conditions, adequate compensation, good supervision, job security, status and responsibilities as well as flexible rules. While internal factors, namely: the desire to be able to live, the desire to be able to have, the desire to obtain appreciation, the desire to obtain recognition and the desire to rule.

\section{METHOD}

The research design that will be used in this research is causality. This design aims to determine the cause and effect between one variable with another variable. So that we can know the variables that influence, and variables that are affected. Given the number of employees in the business environment of PT. Loka Indah Lestari in Popayato Barat District, Pohuwato Regency is less than 100, namely 74 employees, so based on the provisions above, this study uses total sampling.

\section{RESULT AND DISCUSSION}

The test results show that the $\mathrm{t}$ count is 3,975 . This value has a fairly large range when compared with a ttable value of only 1.666. Thus it can be concluded that there is an influence of the work environment on work motivation by $39.75 \%$ in employees of PT. Loka Indah Lestari. In this case there is certainly a phonum because of the company's lack of attention to employees related to the work environment, especially road access, inadequate communication media (signals), and lack of access to government electricity. Significance value of 0,000 or smaller than the predetermined standard that is 0.05 indicates that the influence of the work environment on employee work motivation is very significant, which means that the level of motivation of employees at the company is largely determined by how the conditions of the work environment.

Table 1. Comparison of $T$ Values

\begin{tabular}{|c|c|c|c|}
\hline $\mathbf{N}$ & $\mathbf{t}_{\text {count }}$ & $\mathbf{t}_{\text {table }}$ & Signification \\
\hline 74 & 3,975 & 1,666 & 0,000 \\
\hline
\end{tabular}

Source: Data Processed

The test results show that the $\mathrm{t}$ count is 3,975 . This value has a fairly large range when compared with a ttable value of only 1.666. Thus it can be concluded that there is an influence of the work environment on work motivation by $39.75 \%$ in employees of PT. Loka Indah Lestari. In this case there is certainly a 
phonum because of the company's lack of attention to employees related to the work environment, especially road access, inadequate communication media (signals), and lack of access to government electricity. Significance value of 0,000 or smaller than the predetermined standard that is 0.05 indicates that the influence of the work environment on employee work motivation is very significant, which means that the level of motivation of employees at the company is largely determined by how the conditions of the work environment.

Based on the existing model, it can be seen the value $\hat{Y}=10.737+0.447$

\section{CONCLUSSION}

Based on the results of testing and discussion, the researcher can conclude that there is a significant influence between the work environment on the work motivation of employees of PT. Loka Indah Lestari in Popayato Barat District, Pohuwato Regency, with a correlation value of 0.447 and a close relationship ( $R$ Square) of $18 \%$.

\section{SUGGESTION}

From the conclusions above, the researchers suggest the following three things to the company.

1. Make improvements to the company environment. The company must be able to strive for adequate work facilities in terms of road access, which translates that the beginning of work motivation (variable $\mathrm{Y}$ ) has a constant value of 10.737 which means that when there is no influence of the independent variable $\mathrm{X}$ (Work Environment) on the dependent variable Y (Work Motivation) ), Then obtained a value of 10.737 per unit of work motivation. While the Regression Coefficient of $\mathrm{X}$ is 0.447 or $44.7 \%$ which means that every $1 \%$ increase of the variable $\mathrm{X}$ (Work Environment), the value of the partition will increase by 0.447 . The coefficient is positive, so the effect of the independent variable $(\mathrm{X})$ on the dependent variable $(\mathrm{Y})$ is said to be positive.

cellular network coverage, and government electricity (PLN) for its employees.

2. Maximizing motivator working environment in order to encourage employee morale.

3. The more conducive the atmosphere of the environment in which employees work, the more work motivation of employees will also increase. So as to achieve maximum performance, companies must pay close attention to the needs of their employees for work facilities.

\section{REFERENCESS}

Hasibuan, Malayu. (2012). Manajemen Sumber Daya manusia. Jakarta: PT. Bumi Aksara.

Mangkunegara, Anwar Prabu. (2008) Manajemen Sumber daya Manusia 
Perusahaan, Cetakan Kedua. Bandung: Ramaja Rosdakarya,.

Mardiana, (2005) Manajemen Produksi. Jakarta: Penerbit Badan Penerbit IPWI. .

Sedarmayanti. (2017). Perencanaan Dan Pengembangan Sumber Daya Manusia. Refika Aditama: Bandung
Sugiyono. (2016). Metode Penelitian Manajemen.Alfabeta: Bandung

Sutrisno, Edy. (2011). Manajemen Sumber Daya Manusia. Jakarta: Kecana Prenada Media Group.

Widodo, Suparno Eko. (2015) Manajemen Pengembangan Sumberdaya Manusia. Cetakan Kedua. Jakarta: Pustaka Pelajar. 